\title{
Laboratory Evaluation of Eco-Friendly Pervious Concrete Pavement Material Containing Silica Fume
}

\author{
Hanbing Liu ${ }^{1}$, Guobao Luo ${ }^{1}\left(\mathbb{D}\right.$, Longhui Wang ${ }^{2}$, Wensheng Wang ${ }^{1}{ }^{\circledR}$, Wenjun $\operatorname{Li}^{1}$ and \\ Yafeng Gong ${ }^{1, *}$ \\ 1 College of Transportation, Jilin University, Changchun 130025, China; liuhb@jlu.edu.cn (H.L.); \\ luogb17@mails.jlu.edu.cn (G.L.); wangws17@mails.jlu.edu.cn (W.W.); wenjun18@mails.jlu.edu.cn (W.L.) \\ 2 China Construction Eighth Engineering Division Corp Ltd., Shanghai 200135, China; protein1@163.com \\ * Correspondence: gongyf@jlu.edu.cn; Tel.: +86-0431-8509-5446
}

Received: 22 November 2018; Accepted: 19 December 2018; Published: 26 December 2018

\begin{abstract}
Pervious concretes, such as sustainable pavement materials, have great advantages in solving urban flooding, promoting urban ecological balance, and alleviating urban heat island effect, due to its special porous structure. However, pervious concrete typically has high porosity and low strength. The insufficient strength and poor freeze-thaw durability are important factors that restrict its wide application, especially in seasonal frozen areas. Improving the strength and freeze-thaw resistance of pervious concrete will expand its application. Silica fumes, as an industrial by-product waste and supplementary cementitious material, play an important role in improving concrete performance. The objective of this paper was to study the effects of silica fumes on properties of sustainable pervious concrete. Silica fumes were used to replace cement with the equivalent volume method at different levels $(3 \%, 6 \%, 9 \%$, and $12 \%)$. The control pervious concrete and silica fume-modified pervious concrete mixtures were prepared in the lab. The porosity, permeability, compressive strength, flexural strength, and freeze-thaw resistance properties of all mixtures were tested. The results indicated that the addition of silica fumes significantly improved the strength and freeze-thaw resistance of pervious concrete. The porosity and permeability of all pervious concrete mixtures changed little with the content of silica fumes due to the adoption of the equal volume replacement method.
\end{abstract}

Keywords: pervious concrete; silica fume; freeze-thaw resistance; porosity; permeability; compressive strength; flexural strength

\section{Introduction}

In recent years, urban floods have occurred frequently and caused huge casualties and property loss, due to the imperfect urban stormwater management system and large-area impervious pavement [1-7]. In order to solve this problem, sustainable pavement material-pervious concrete- has been developed. Pervious concrete was first used in the 1970s in the United States [8]. However, it has not been widely used in the world. At the beginning of the 21st century, pervious concrete regained the attention of researchers and engineers due to the emergence of various urban problems, such as urban floods, urban heat island effects, groundwater decline, etc. [4,9-12]. Compared with traditional concrete, pervious concrete, as a porous material with high porosity, has great advantages [13-16]. First, it is an excellent and effective material in solving urban stormwater. It can allow stormwater permeating into underground, reduce surface water runoff, and improve the slip resistance of roads [13]. On the other hand, water infiltrated from pervious concrete can quickly recharge groundwater and improve urban ecological environments [14]. In addition, its high porosity is able to accumulate more heat, regulate city temperature and humidity, and alleviate heat island 
effect [15]. What's more, the high porosity of pervious concrete can absorb the noise generated by vehicles and create a safe and comfortable driving environment [16]. All these make pervious concrete sustainable and environmentally friendly material. However, some shortcomings still restrict its wide applications [17-19]. The main disadvantages of pervious concrete are its low strength and poor durability, especially for freeze-thaw resistance in seasonal frozen areas [19]. It therefore becomes the focus of current research how to improve strength and durability of pervious concrete without sacrifice of permeability.

Silica fume is the by-product waste of industrial silicon production with high content of $\mathrm{SiO}_{2}$, and has always been an excellent supplementary cementitious material [20]. Due to their small particle size and large specific surface area, silica fumes can fill in the pores between the cement particles and increase the density and strength of the cement binder. Generally, the $\mathrm{SiO}_{2}$ in silica fumes is up to $90 \%$, it can react with the cement hydration product $\left(\mathrm{Ca}(\mathrm{OH})_{2}\right)$, and form a pozzolanic $\mathrm{C}-\mathrm{S}-\mathrm{H}$ gel, which improves the property of traditional $\mathrm{C}-\mathrm{S}-\mathrm{H}$ gel and strengths the bonding between the hardened cement binder and the aggregate. On the other hand, the micro-aggregate effect of silica fumes can optimize the microscopic pore structure of the cement paste, and thus increase the strength of the concrete $[21,22]$. Based on the superior performance, silica fumes have been widely used in traditional cement concrete as a modifier.

The positive effects of silica fume on cement concrete properties have been reported by many researchers. Zivika V. [23] studied the improvement of silica fumes on cement concrete durability. The results indicated that the addition of silica fumes increased the sulfate resistance of cement concrete. Wu et al. [24] investigated the effect of silica fumes on fresh and aged mechanical properties. In this study, the durability of coral aggregate concrete, the compressive strength, splitting tensile strength, chloride penetration, and micro-hardness of the interfacial transition zone were measured. Compared with the control group, silica fumes significantly improved compressive strength, splitting tensile strength, chloride penetration, and micro-hardness of the interfacial transition zone of coral aggregate concrete. Zhu et al. [25] conducted experiments on silica fume-modified engineered cementitious composites; the ductility and compressive strength were tested. The results showed that the addition of silica fumes increased the compressive strength, but decreased the ductility of engineered cementitious composites. Zhang et al. [26] conducted the experiments on silica fume-modified concrete. The results indicated that the addition of silica fume increased the hydration degree of cement paste, improved the properties of interfacial transition zone between hardened paste and aggregate, and enhanced the compressive strength. In summary, the addition of silica fumes can significantly improve the compressive strength, erosion resistance, freeze-thaw resistance, impact resistance, etc.

However, there are few studies on the application of silica fumes in pervious concrete. The effect of silica fumes on pervious concrete needs further research. Amornsrivilai et al. [27] studied the permeability of silica fume-modified porous limestone aggregate concrete. The silica fume content was selected as $5-20 \%$ of cement by weight. The test results showed that the addition of silica fumes had considerable effects on both water and rapid chloride permeability of concrete. Mondal and Biligiri [28] conducted experiments to comprehensively investigate the hydrological, functional, and structural characteristics of pervious concrete with four proportions of silica fumes and three aggregate gradations. The results indicated that the compressive strength of pervious concrete was enhanced by the addition of silica fumes. Zhang et al. [29] investigated the porous silicate material derived from silica fume with X-ray diffraction. The microstructure of porous silicate material was analyzed and the preparation of it was studied. Mann D.A. [30] studied the effects of silica fume on the workability and compressive strength of pervious concrete. Silica fumes were used as the replacement of Portland cement with the content of $0-10 \%$. The results indicated that, when the silica fume content was less than $5 \%$, the mixtures had comparable or slightly improved workability compared to control groups, when the silica fume content was $7 \%$, workability was decreased. The $28 \mathrm{~d}$ compressive strength increased with the dosage of 3-5\%, but decreased when the dosage reached $7 \%$, which was different from other researches. Zerdi et al. [31] investigated the compressive strength of 
silica fume-modified pervious concrete with three mix ratios. The test results indicated the compressive strength of the three mixtures increased by $86 \%, 52 \%$, and $48 \%$, respectively when $10 \%$ silica fumes were incorporated. Such a high improvement on compressive strength deserved further research to confirm.

There are few studies concentrating on silica fume-modified pervious concrete. Existing research mainly focuses on the strength properties of silica fume-modified pervious concrete, and the conclusions obtained are quite different. Moreover, there is almost no research concentrating on its durability. Therefore, it is necessary to carry out research to investigate the mechanical properties and durability of silica fume-modified pervious concrete. Based on previous research conducted by our group [32,33], in order to evaluate the improvement of silica fumes on pervious concrete, silica fume-modified pervious concrete was prepared with equivalent volume method, the porosity, permeability, strength, and freeze-thaw durability of silica fume-modified pervious concrete with different silica fume incorporation levels were studied. Due to the porous structure of pervious concrete, strength loss was adopted to assess the freeze-thaw resistance for pervious concrete. The findings of this study will aid in understanding the positive effect of silica fumes on the strength and freeze-thaw durability of pervious concrete, and would certainly help in the futuristic development of rational design and application pertaining to silica fume-modified pervious concrete pavements.

\section{Materials and Methods}

\subsection{Materials}

The main materials used in the study were coarse aggregate, cement, silica fume, water, and superplasticizer. The physical properties of coarse aggregate are shown in Table 1. Portland cement (P.O 42.5) was obtained from Jilin Yatai Cement Co., Ltd. (Jilin, China), and its physical properties and chemical composition are shown in Tables 2 and 3, respectively. Silica fume was provided by Changchun Siao Technology Co., Ltd. (Jilin, China), and its chemical composition is shown in Table 3. The density of silica fumes is $2178 \mathrm{~kg} / \mathrm{m}^{3}$, and its average particle size is $0.1-0.3 \mu \mathrm{m}$. The polycarboxylic acid superplasticizer produced by Shanxi Qinfen Building Material Co., Ltd. (Shanxi, China), was used to improve the workability of pervious concrete.

Table 1. Properties of coarse aggregate.

\begin{tabular}{cc}
\hline Physical Property & Index \\
\hline Type & natural granite coarse aggregate \\
Size $(\mathrm{mm})$ & $4.75-9.5$ \\
Apparent density $\left(\mathrm{kg} / \mathrm{m}^{3}\right)$ & 2786 \\
Bulk density $\left(\mathrm{kg} / \mathrm{m}^{3}\right)$ & 1534 \\
Bulk porosity $(\%)$ & 44.9 \\
Crushing value $(\%)$ & 9.7 \\
Needle-like particle content $(\%)$ & 7.1 \\
Water absorption $(\%)$ & 1.63 \\
\hline
\end{tabular}

Table 2. Physical properties of Portland cement.

\begin{tabular}{|c|c|c|c|c|c|c|c|}
\hline \multirow{2}{*}{$\begin{array}{l}\text { Density } \\
\left(\mathrm{g} / \mathrm{cm}^{3}\right)\end{array}$} & \multirow{2}{*}{$\begin{array}{l}\text { Specific } \\
\text { Surface Area } \\
\left(\mathrm{m}^{2} / \mathrm{kg}\right)\end{array}$} & \multicolumn{2}{|c|}{ Setting Time (min) } & \multicolumn{2}{|c|}{$\begin{array}{l}\text { Compressive } \\
\text { Strength (MPa) }\end{array}$} & \multicolumn{2}{|c|}{$\begin{array}{l}\text { Flexural } \\
\text { Strength (MPa) }\end{array}$} \\
\hline & & Initial Setting & Final Setting & $3 d$ & $28 d$ & $3 d$ & $28 d$ \\
\hline 2.96 & 342 & 182 & 251 & 21.8 & 47.6 & 4.7 & 7.5 \\
\hline
\end{tabular}


Table 3. Chemical composition of Portland cement and silica fumes.

\begin{tabular}{lllllll}
\hline \multirow{2}{*}{ Materials } & \multicolumn{6}{l}{ Chemical Composition (\%) } \\
\cline { 2 - 7 } & $\mathrm{SiO}_{\mathbf{2}}$ & $\mathrm{Al}_{\mathbf{2}} \mathrm{O}_{\mathbf{3}}$ & $\mathbf{C a O}$ & $\mathbf{M g O}$ & $\mathrm{Fe}_{\mathbf{2}} \mathrm{O}_{\mathbf{3}}$ & $\mathrm{SO}_{\mathbf{3}}$ \\
\hline Cement & 22.6 & 5.6 & 62.7 & 1.7 & 4.3 & 2.5 \\
Silica Fume & 93.3 & 0.73 & 0.85 & 1.21 & 0.49 & 1.02 \\
\hline
\end{tabular}

\subsection{Mix Design}

The mix of pervious concrete was designed with the volume method, in accordance with the Chinese standard CJJ/T 135-2009 [34]. Silica fume-modified pervious concrete was prepared in the experiment. In addition, pervious concrete without silica fume was prepared as the control group. Silica fumes were incorporated at different levels to partially replace the cement using the equivalent volume method. The replacement levels were 3\%, $6 \%, 9 \%$, and $12 \%$, respectively. Based on previous research conducted by our group [32], the aggregate size, designed porosity, and water to binder ratios were chosen as $4.75-9.5 \mathrm{~mm}, 15 \%$, and 0.30 , respectively. In order to improve workability of pervious concrete, superplasticizer was used and the dosage was $0.8 \%$ of the cementitious material mass. The mix ratio is shown in Table 4, and the gradation curve of coarse aggregate is shown in Figure 1.

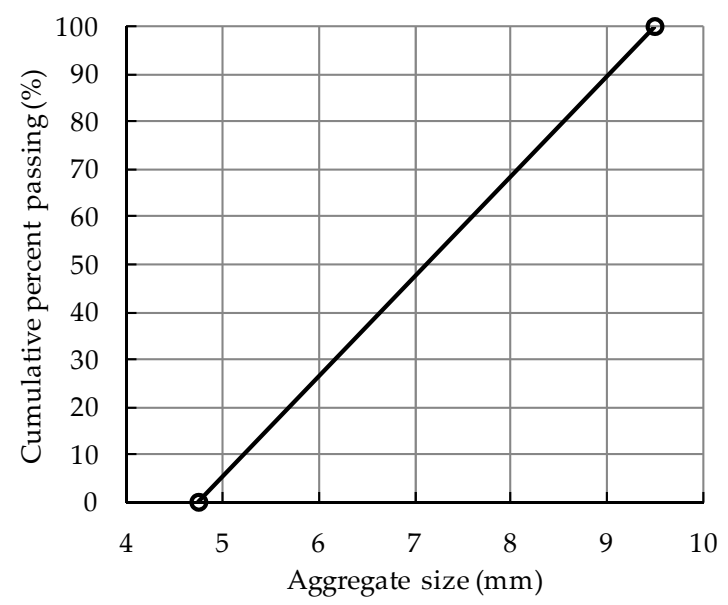

Figure 1. Gradation curve of selected pervious concrete mixture design.

Table 4. Mix ratio of pervious concrete (in $\mathrm{kg} / \mathrm{m}^{3}$ ).

\begin{tabular}{llllll}
\hline Mix ID & Coarse Aggregate & Cement & Silica Fume & Water & Superplasticizer \\
\hline Control & 1503.3 & 479.9 & 0 & 144.0 & 3.84 \\
SF-3 & 1503.3 & 462.9 & 14.3 & 143.2 & 3.82 \\
SF-6 & 1503.3 & 446.1 & 28.5 & 142.4 & 3.80 \\
SF-9 & 1503.3 & 429.5 & 42.5 & 141.6 & 3.78 \\
SF-12 & 1503.3 & 413.0 & 56.3 & 140.8 & 3.75 \\
\hline
\end{tabular}

\subsection{Specimen Preparation}

According to the tests, there were three $100 \times 100 \times 400 \mathrm{~mm}$ prismatic specimens, and fifteen $100 \times 100 \times 100 \mathrm{~mm}$ cubic specimens that required preparation in each group. The prismatic specimens were used to determine the flexural strength. The cubic specimens were used for porosity, permeability, compressive strength, and freeze-thaw cycle tests. A total of 75 cubic specimens and 15 prismatic specimens were prepared in the lab for the experiments. The experimental programme is shown in Table 5, and the specimen preparation procedure is shown in Figure 2. All specimens were demoulded after $24 \mathrm{~h}$. Then, all specimens were standard-cured with a relative humidity of $95 \%$, and a temperature 
of $20 \pm 2{ }^{\circ} \mathrm{C}$. The specimens for porosity, permeability, compressive strength, and flexural strength were standard-cured for 28 days. Specimens for the freeze-thaw cycles were standard-cured for 24 days, and submerge-cured for four days. All tests were immediately conducted at the age of 28 days.

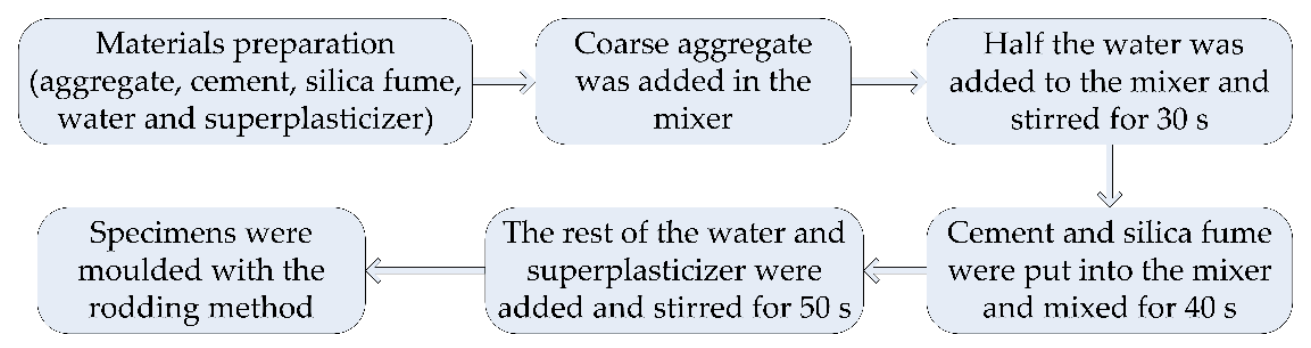

Figure 2. Specimen preparation procedure.

Table 5. The experimental programme.

\begin{tabular}{lll}
\hline Test & $\begin{array}{l}\text { Number of Specimens in } \\
\text { Each Group }\end{array}$ & Test Condition/Set-Up \\
\hline Porosity & 3 cubic specimens & $\begin{array}{l}\text { The porosity, permeability and compressive } \\
\text { strength tests can adopt } 3 \text { same specimens } \\
\text { and the test sequence is: porosity, } \\
\text { permeability, compressive strength. Test } \\
\text { temperature: } 20 \pm 2{ }^{\circ} \mathrm{C} .\end{array}$ \\
\hline Permeability & 3 cubic specimens & Test temperature: $20 \pm 2{ }^{\circ} \mathrm{C}$. \\
\hline Flexural strength & 3 prismatic specimens & $\begin{array}{l}\text { Highest temperature: } 5{ }^{\circ} \mathrm{C}, \text { lowest } \\
\text { temperature: }-18^{\circ} \mathrm{C}\end{array}$ \\
\hline Freeze-thaw cycle & $\begin{array}{l}12 \text { cubic specimens } \\
\text { (4 freeze-thaw levels, } \\
3 \text { for each level). }\end{array}$ & \\
\hline
\end{tabular}

\subsection{Testing Methods}

Porosity is a characteristic of pervious concrete, and it is directly related to permeability. The effective porosities (proportion of open pore and semi-open pore) of all mixtures were tested. The effective porosity was characterized by the average of three specimens and determined using the equation,

$$
P=\left(1-\frac{m_{1}-m_{0}}{V \rho}\right) \times 100 \%
$$

where $m_{0}$ is the mass of the specimen submerged in water $(\mathrm{g}) ; m_{1}$ is the saturated surface-dry mass of the specimen $(\mathrm{g}) ; \rho$ is the water density $\left(\mathrm{g} / \mathrm{cm}^{3}\right)$, and $V$ is the volume of the specimen $\left(\mathrm{cm}^{3}\right)$.

Permeability is the most important property of pervious concrete. According to the Chinese national standard CJJ/T 135-2009 [34], the constant head permeability test was adopted and the homemade instrument was used to measure the permeability coefficient. Detailed description of the permeability instrument is shown in Figure 3. A detailed description of the test procedure could be found elsewhere [33]. In every group, the permeability was characterized by the average permeability coefficients of three specimens. The permeability coefficient can be calculated by the following equation according to the Chinese national standard [34]:

$$
k=\frac{Q L}{A H t}
$$

where $k$ is the permeability coefficient of the specimen at $20^{\circ} \mathrm{C}(\mathrm{mm} / \mathrm{s}) ; Q$ is the discharged amount of water in $\mathrm{t}$ time $\left(\mathrm{mm}^{3}\right) ; L$ is the height of the specimen $(\mathrm{mm}) ; A$ is the upper surface area of the specimen $\left(\mathrm{mm}^{2}\right) ; H$ is the height of water head $(\mathrm{mm})$, and $H=150 \mathrm{~mm}$; and $t$ is the time (s), with $t=300 \mathrm{~s}$. 


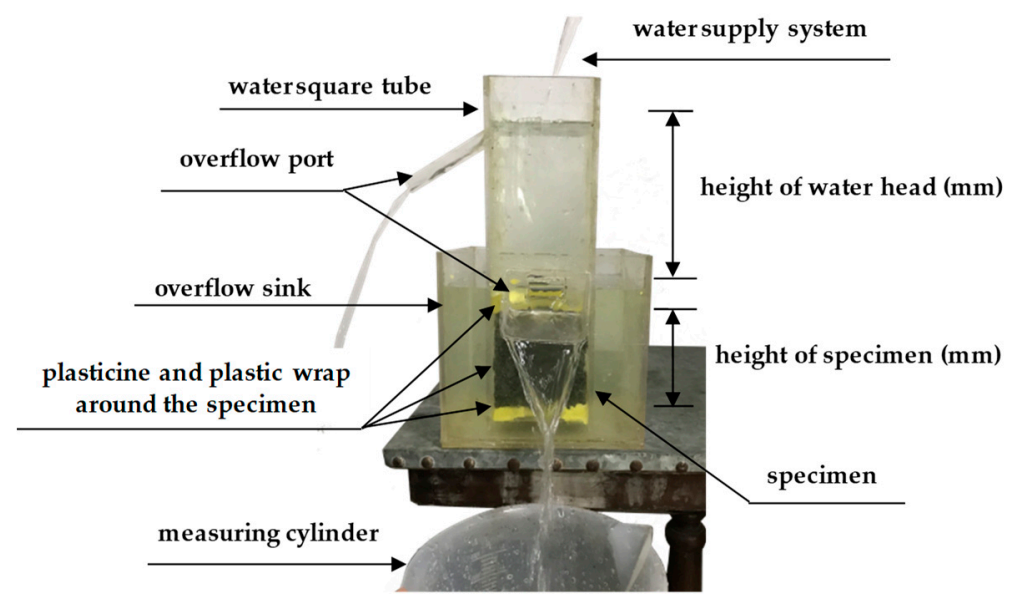

Figure 3. Homemade permeability measure instrument.

Compressive strength and flexural strength tests were conducted in accordance with the Chinese national standard GB/T 50081-2002 [35]. The compressive strength test was conducted with a hydraulic pressure testing machine, and the flexural strength was conducted with a closed-loop, servo-controlled hydraulic testing system. The loading rates for compressive strength and flexural strength were $5 \mathrm{kN} / \mathrm{s}$ and $0.05 \mathrm{kN} / \mathrm{s}$, respectively. The third-point bending test, shown in Figure 4, was adopted to determine the flexural strength. In each group, three specimens were tested and the average compressive and flexural strengths were calculated to characterize the strength property. The compressive and flexural strengths can be calculated by following equations:

$$
\begin{gathered}
f_{c}=\frac{F}{A} \\
f_{f}=\frac{3}{2} \frac{F L}{b h^{2}}
\end{gathered}
$$

where $f_{c}$ is the compressive strength of the specimen $(\mathrm{MPa}) ; f_{f}$ is the flexural strength of the specimen $(\mathrm{MPa}) ; A$ is the pressure-bearing surface area of the specimen; $F$ is the failure load $(\mathrm{N}) ; L$ is the distance between two supporting points $(\mathrm{mm}), L=300 \mathrm{~mm}$; $b$ is the section width of the specimen $(\mathrm{mm})$, $b=100 \mathrm{~mm} ; h$ is height of the specimen $(\mathrm{mm}), h=100 \mathrm{~mm}$.

\section{the closed-loop, servo-controlled hydraulic testing system}

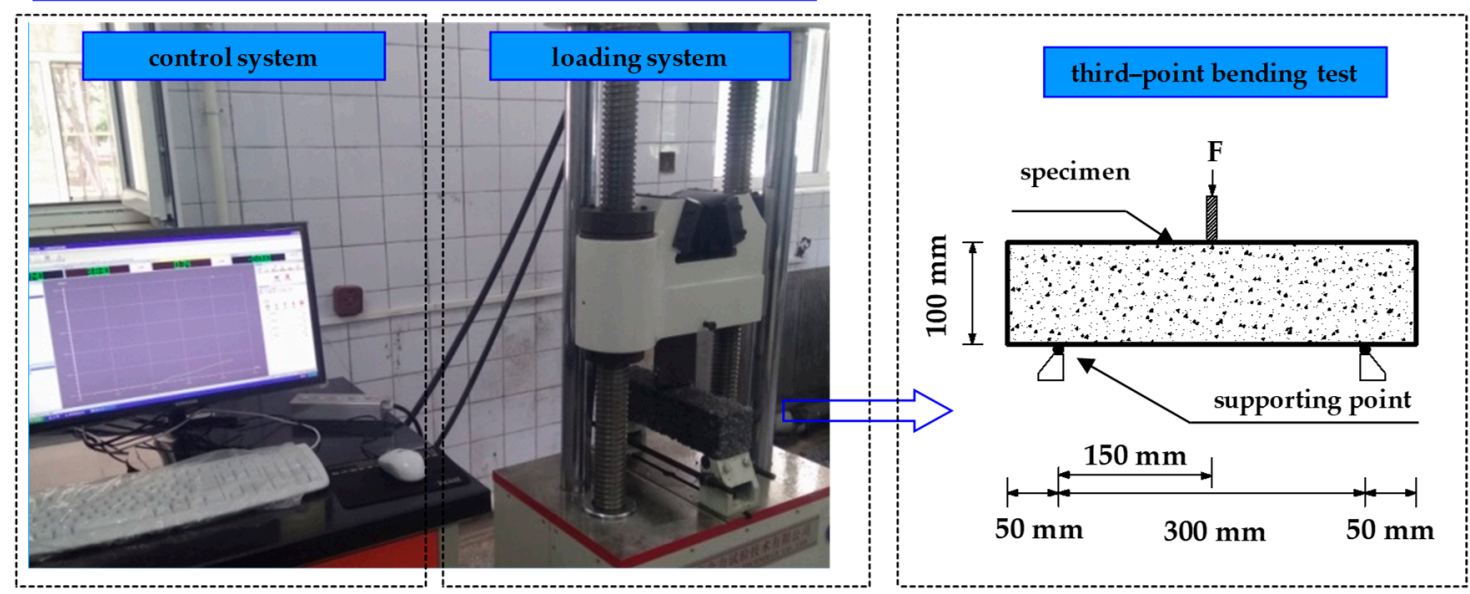

Figure 4. Flexural strength test.

The fast freezing method was adopted to conduct a freeze-thaw cycles test according to the Chinese standard GB/T 50082-2009 [36]. Levels of the freeze-thaw cycles were set to 25, 50, 75, 
and 100 cycles. In each freeze-thaw cycles level, three cubic specimens were used. Compared to the non-destructive testing method, in this paper, the compressive strength after freeze-thaw cycles was measured and the compressive strength loss was chosen as the evaluation index for freeze-thaw resistance. The detailed explanation for choosing compressive strength loss can be found elsewhere [32]. The compressive strength after freeze-thaw cycles was characterized by the average strength of three specimens. Compressive strength loss at the corresponding level was calculated based on the compressive strength of specimens under zero freeze-thaw cycle. The termination condition of freeze-thaw cycles was that the specimens underwent 100 cycles, or the compressive strength loss exceeded $25 \%$. The freeze-thaw cycles test is shown in Figure 5. Specimens after 100 freeze-thaw cycles are shown in Figure 6.

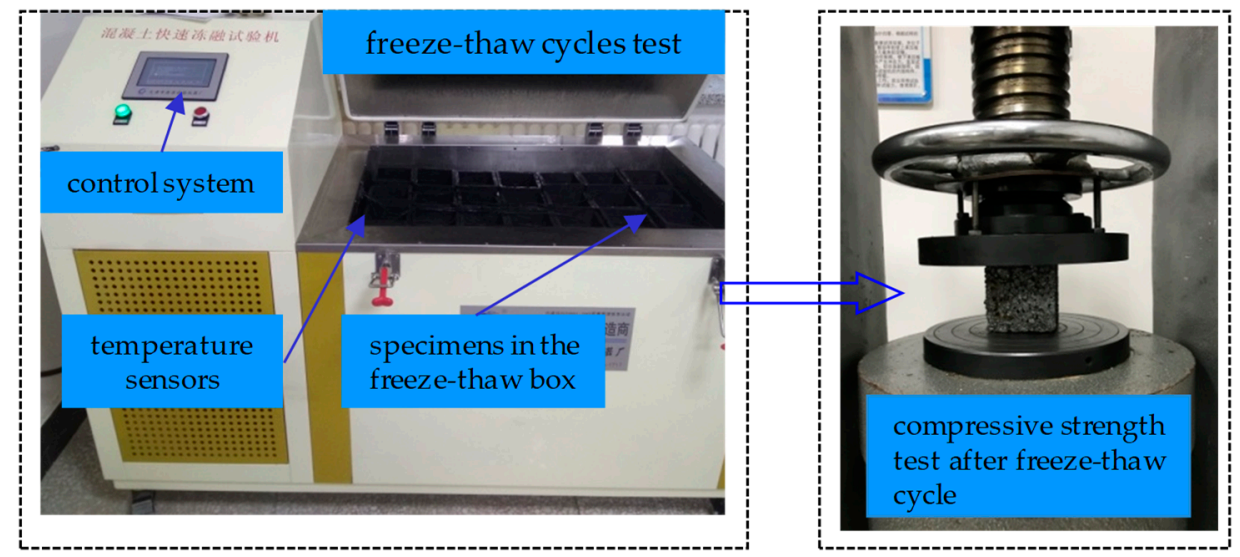

Figure 5. Freeze-thaw cycle and compressive strength test after freeze-thaw cycles.

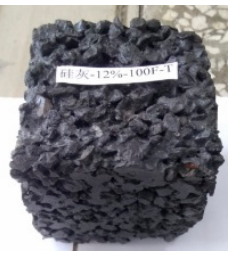

(a)

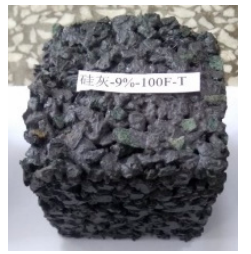

(b)

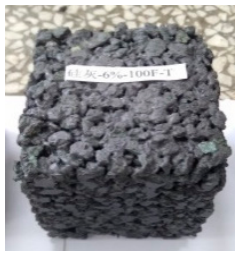

(c)

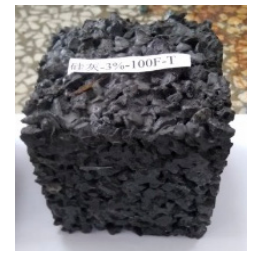

(d)

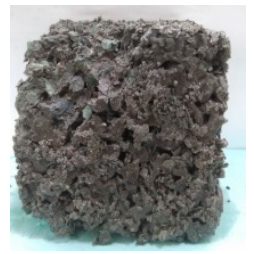

(e)

Figure 6. Specimens after 100 freeze-thaw cycles: (a) 12\% silica fume-modified specimen; (b) 9\% silica fume-modified specimen; (c) $6 \%$ silica fume-modified specimen; (d) 3\% silica fume-modified specimen; and (e) $0 \%$ silica fume-modified specimen.

\section{Results and Discussion}

The summary of the compressive strength, flexural strength, porosity, and permeability results with the standard deviations are tabulated in Table 6, the freeze-thaw cycles result is shown in Table 7.

Table 6. Strength and permeability results for silica fume-modified pervious concrete.

\begin{tabular}{|c|c|c|c|c|c|c|c|c|}
\hline \multirow[t]{2}{*}{ Mix ID } & \multicolumn{2}{|c|}{ Porosity (\%) } & \multicolumn{2}{|c|}{$\begin{array}{l}\text { Permeability } \\
\text { Coefficient }(\mathrm{mm} / \mathrm{s})\end{array}$} & \multicolumn{2}{|c|}{$\begin{array}{l}\text { Compressive } \\
\text { Strength (MPa) }\end{array}$} & \multicolumn{2}{|c|}{$\begin{array}{l}\text { Flexural Strength } \\
\text { (MPa) }\end{array}$} \\
\hline & Mean & St. Dev. & Mean & St. Dev. & Mean & St. Dev. & Mean & St. Dev. \\
\hline Control & 14.0 & 0.4 & 3.91 & 0.12 & 22.2 & 0.50 & 4.84 & 0.09 \\
\hline SF-3 & 13.7 & 0.3 & 3.85 & 0.17 & 23.6 & 0.52 & 4.91 & 0.06 \\
\hline SF-6 & 14.5 & 0.3 & 3.93 & 0.13 & 24.8 & 0.42 & 5.09 & 0.11 \\
\hline SF-9 & 13.4 & 0.5 & 3.79 & 0.09 & 25.3 & 0.53 & 5.19 & 0.08 \\
\hline SF-12 & 13.8 & 0.2 & 3.82 & 0.11 & 25.3 & 0.45 & 5.20 & 0.06 \\
\hline
\end{tabular}


Table 7. Freeze-thaw cycle results of silica fume-modified pervious concrete.

\begin{tabular}{|c|c|c|c|c|c|c|c|c|}
\hline \multirow[b]{2}{*}{ Mix ID } & \multicolumn{8}{|c|}{ Compressive Strength And Its Loss Rate After Freeze-Thaw Cycles } \\
\hline & $\begin{array}{l}25 \text { Cycles } \\
\mathrm{CS}^{1}(\mathrm{MPa})\end{array}$ & $\mathrm{L}^{2}(\%)$ & $\begin{array}{l}50 \text { Cycles } \\
\text { CS (MPa) }\end{array}$ & $L(\%)$ & $\begin{array}{l}75 \text { Cycles } \\
\text { CS (MPa) }\end{array}$ & L (\%) & $\begin{array}{l}100 \text { Cycles } \\
\text { CS (MPa) }\end{array}$ & L (\%) \\
\hline Control & 21.2 & 4.5 & 18.1 & 18.5 & 16.7 & 24.8 & 14.2 & 36.0 \\
\hline SF-3 & 22.6 & 4.2 & 21.5 & 8.9 & 20.2 & 14.4 & 17.9 & 24.2 \\
\hline SF-6 & 23.8 & 4.0 & 22.5 & 9.3 & 20.8 & 16.1 & 19.3 & 22.2 \\
\hline SF-9 & 24.2 & 4.3 & 23.1 & 8.7 & 21.6 & 14.6 & 20.7 & 18.2 \\
\hline SF-12 & 24.7 & 2.4 & 24.1 & 4.7 & 23.5 & 7.1 & 22.9 & 9.5 \\
\hline
\end{tabular}

\subsection{Porosity}

The effective porosity of silica fume-modified pervious concrete is shown in Figure 7. As we can see, the incorporation level of silica fumes had little effect on the effective porosity of silica fume-modified pervious concrete. This is because the cement was partially replaced by silica fume with the equivalent volume method, thus the addition of silica fumes did not cause the change in the volume of the specimen. In addition, the effective porosities measured for all mixtures were less than the designed porosity of $15 \%(13.4-14.5 \%)$. As we all know, the pore in previous concrete is composed of open, semi-open, and closed pores, the effective porosity only includes open and semi-open pores, so the effective porosity is generally lower than the total porosity. This also indicates that the preparation of the specimen was successful and reached the design requirement.

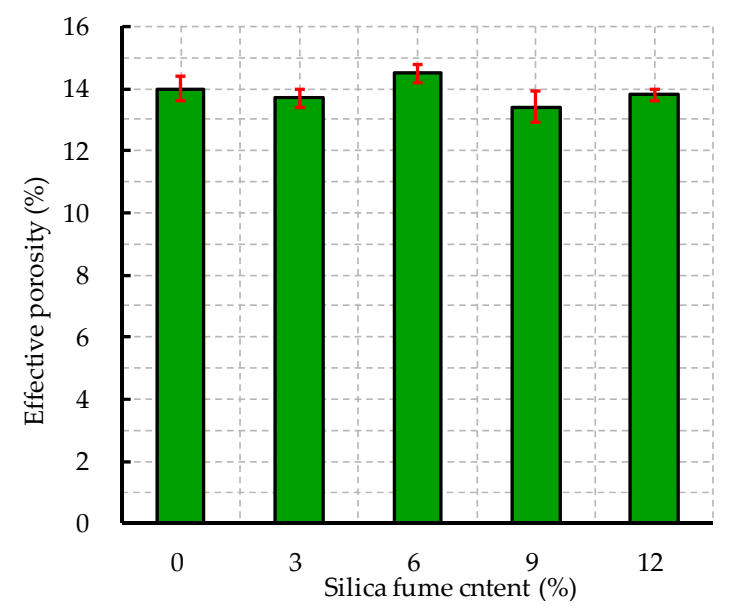

Figure 7. Porosity of silica fume-modified pervious concrete.

\subsection{Permeability}

The permeability coefficient of silica fume-modified pervious concrete is shown in Figure 8. Figure 8 concludes that the permeability coefficient was not affected by the dosage of silica fumes. The permeability coefficients of all groups were about $3.8 \mathrm{~mm} / \mathrm{s}$ when the porosities of all mixtures were about $15 \%$, which meets the standard requirement of $0.5 \mathrm{~mm} / \mathrm{s}$ for pervious concrete in the Chinese national standard [34]. Just as the report in the literature [32], the porosity is the most important and direct factor that determines the permeability coefficient of pervious concrete. In terms of mono-sized pervious concrete, when the porosity does not change, the permeability will not change. Silica fumes were added with equivalent volume replacement of cement in the experiment, and the porosity volume did not change with the silica fume incorporation levels, so the permeability coefficients of silica fume-modified concrete remained constant.

Meanwhile, the permeability coefficients of all mixtures were predicted with the equation between effective porosity and permeability given by Reference [32], and the predicted permeability coefficients 
are also shown in Figure 8 . The data shows that the measured and predicted permeability coefficients were basically consistent and the maximum error between them was $6.5 \%$.

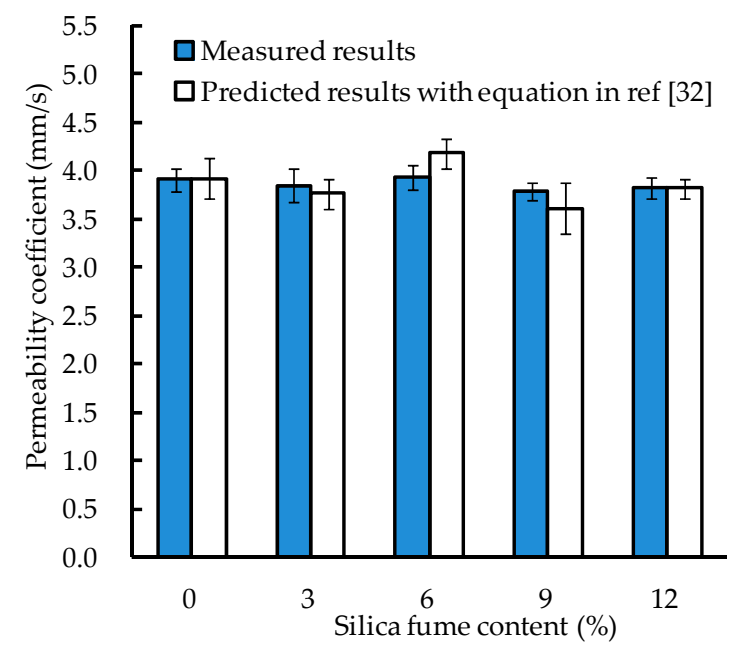

Figure 8. Permeability coefficient of silica fume-modified pervious concrete.

\subsection{Compressive Strength}

Insufficient strength of pervious concrete has always been the main factor restricting its wide application. Due to its low strength, pervious concrete is generally applied to non-loaded pavements. Improving the strength of pervious concrete has always been the focus and hotspot of research. The compressive strength of the silica fume-modified pervious concrete of this experiment is shown in Figure 9. It can be seen that the addition of silica fumes improved the compressive strength of the pervious concrete. The compressive strengths of all groups met the standard requirement of $20 \mathrm{MPa}$ for pervious concrete in the Chinese national standard [34]. With the increasing amount of silica fumes, the compressive strength gradually increased, and the compressive strength reached maximum when the addition of silica fumes was $9 \%$ and $12 \%$. Compared to the control group ( $0 \%$ silica fume addition), the maximum improvement of the compressive strength of silica fume-modified pervious concrete was $14 \%$. This was because the aggregate of pervious concrete mainly bonded together by the cement paste layer, and the interface characteristics between the bonding layer and aggregate have an important influence on the strength of the pervious concrete. Silica fume is a pozzolanic material that can cause secondary reaction (pozzolanic reaction) with $\mathrm{Ca}(\mathrm{OH})_{2}$ produced by cement hydration to form a volcanic ash C-S-H gel, which improves the property of the traditional cement C-S-H gel and interface characteristics between the hardened cement paste and aggregate. In addition, silica fume has smaller particle size and larger specific surface area than the cement, and the micro-aggregate effect is remarkable. It can fill the harmful pores of the cement paste, make the pore distribution more uniform, and improve the pore structure of the hardened cement paste. Thus the strength of pervious concrete was improved. 


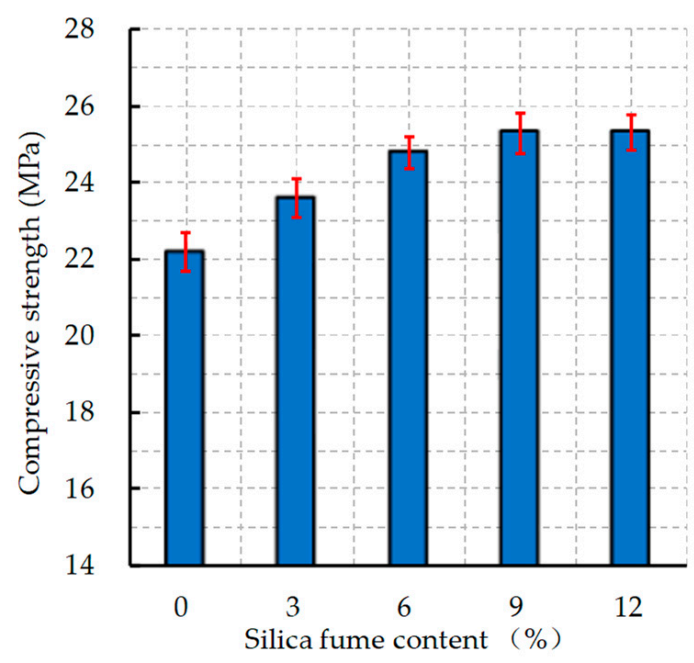

Figure 9. Compressive Strength of silica fume-modified pervious concrete.

\subsection{Flexural Strength}

The variation of flexural strength versus silica fume dosage of silica fume-modified pervious concrete is shown in Figure 10. From the data, it can be concluded that silica fumes also have a positive effect on the flexural strength of pervious concrete. The improvement of silica fumes on flexural strength was the same as its effect on compressive strength. The flexural strengths of all groups were much larger than the requirement of $2.5 \mathrm{MPa}$ in the Chinese national standard [34]. The flexural strength increased with the increasing silica fume content. The control group had a flexural strength of $4.84 \mathrm{MPa}$, while the silica fume-modified groups had the maximum flexural strength of $5.2 \mathrm{MPa}$ with $7.4 \%$ improvement. When the silica fume content was $9 \%$ and $12 \%$, the flexural strengths of the two groups were almost the same. The improvement mechanism of silica fumes on the flexural strength of pervious concrete was the same as it on the compressive strength. The addition of silica fumes improved the interface characteristics between the bonding layer and aggregate, increased the interface adhesion, and thereby improved the flexural resistance of the pervious concrete.

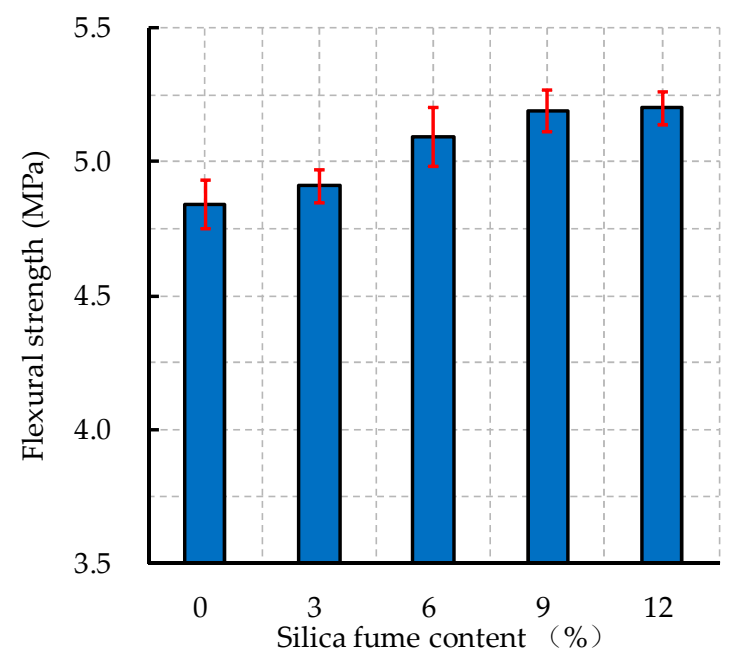

Figure 10. Flexural strength of silica fume-modified pervious concrete.

\subsection{Freeze-Thaw Cycles}

The relationship between compressive strength and freeze-thaw cycles of pervious concrete is shown in Figure 11. As can be seen in Figure 11, for the control group and silica fume-modified groups, the compressive strengths decreased with the increasing freeze-thaw cycles, which indicated 
that the freeze-thaw resistance of pervious concrete gradually degenerates. When the freeze-thaw cycle was the same, the compressive strengths of silica fume-modified pervious concrete were higher than the control group, and the higher the silica fume content, the higher the compressive strength. The compressive strength of control group was reduced to $14.2 \mathrm{MPa}$ after 100 freeze-thaw cycles, while the compressive strength of $9 \%$ and $12 \%$ silica fume-modified groups were still more than $20 \mathrm{MPa}$.

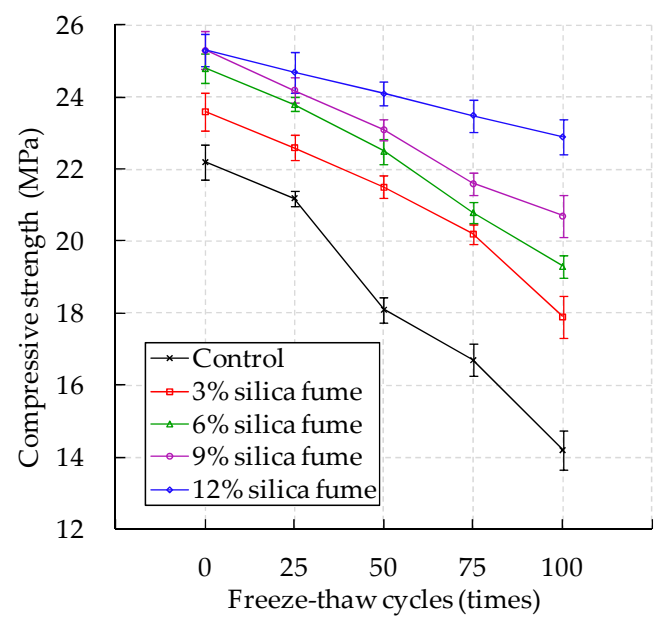

Figure 11. Compressive strength of silica fume-modified pervious concrete under freeze-thaw cycles.

Figure 12 indicates the variation of compressive strength loss versus freeze-thaw cycles of pervious concrete. It can be concluded from Figure 12 that, for all groups, the compressive strength losses gradually increased with the increasing freeze-thaw cycles. Before 25 freeze-thaw cycles, the compressive strength losses of all groups were less than $5 \%$, which met the standard requirement of $20 \%$ in the Chinese national standard [34], after 25 freeze-thaw cycles, the compressive strength losses of the control group increased rapidly while the silica fume-modified groups increased relatively slowly. The control group had the highest compressive strength loss at all freeze-thaw cycle levels than the silica fume-modified groups, which indicated that the addition of silica improved the freeze-thaw resistance of pervious concrete. The $12 \%$ silica fume-modified group had the minimum compressive strength loss in all groups at each level of freeze-thaw cycles, and the maximum compressive strength loss after 100 freeze-thaw cycles was 9.5\%. Figure 6 shows the specimens after 100 freeze-thaw cycles, obvious morphological differences between control group and silica fume-modified groups can be found, concrete spalling appears on the specimen surface of control pervious concrete while the silica fume-modified pervious concrete specimens were nearly intact. This was because the pozzolanic reaction caused by silica fumes improved the interface characteristics and adhesion between cement binder and aggregate, and reduced the concrete deterioration under freeze-thaw cycles. The addition of silica fumes significantly improved the freeze-thaw resistance of pervious concrete. 


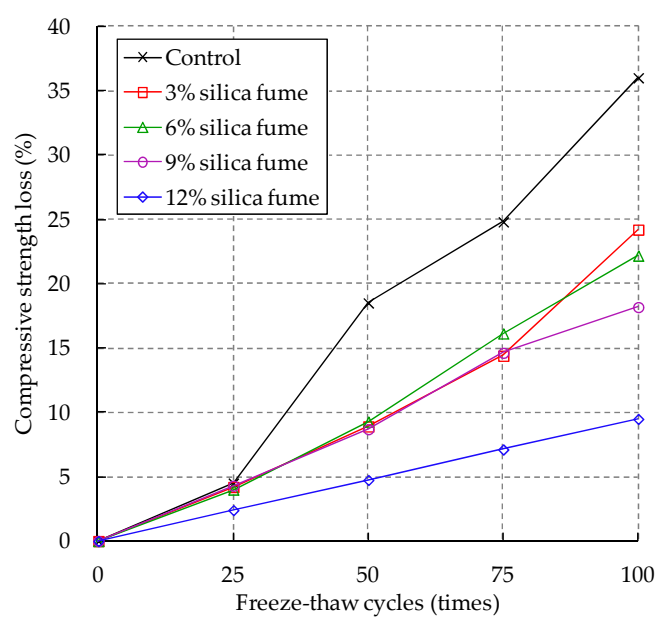

Figure 12. Compressive strength loss of silica fume-modified pervious concrete under freeze-thaw cycles.

\section{Conclusions}

Sustainable pavement materials-silica fume-modified pervious concrete and control pervious concrete-were prepared and investigated in the lab. Porosity, permeability, mechanical properties, and freeze-thaw resistance of pervious concrete were tested. The effects of silica fumes on pervious concrete properties were analyzed. Based on the test results, following conclusions can be drawn.

- The silica fume-modified pervious concrete designed with equivalent volume replacement of cement will not affect the effective porosity, thus the permeability of silica fume-modified pervious concrete hardly changed with the amount of silica fumes compared to the unmodified control pervious concrete.

- The compressive and flexural strengths of pervious concrete can be improved by the addition of silica fumes. The higher the content of silica fumes, the higher the compressive and flexural strengths.

- The addition of silica fumes significantly improves the freeze-thaw resistance of pervious concrete. The compressive strength losses of silica fume-modified pervious concrete under freeze-thaw cycles are obviously lower than the unmodified control pervious concrete. The freeze-thaw resistance of silica fume-modified pervious concrete increases with the increasing silica fume content, and the $12 \%$ silica fume is recommended for freeze-thaw durability of pervious concrete.

Author Contributions: Conceptualization: H.L.; investigation: G.L., H.L., and Y.G.; writing (original draft): W.L., G.L., W.W., and L.W.; writing (review and editing): Y.G.

Funding: This research was funded by the Science Technology Development Program of Jilin Province (grant number 20180201026SF), the Transportation Science and Technology Program of Jilin Province (grant number 2018-1-9), and the Education Department's “13th Five-Year" Science and Technology Program of Jilin Province (grant number JJKH20190015KJ).

Acknowledgments: The authors would like to appreciate the anonymous reviewers for their constructive suggestions and comments to improve the quality of this paper.

Conflicts of Interest: The authors declare no conflicts of interest.

\section{References}

1. Byun, K.; Chiu, C.M.; Hamlet, A.F. Effects of 21st century climate change on seasonal flow regimes and hydrologic extremes over the Midwest and Great Lakes region of the US. Sci. Total Environ. 2019, 650, 1261-1277. [CrossRef]

2. Richards, D.R.; Edwards, P.J. Using water management infrastructure to address both flood risk and the urban heat island. Int. J. Water. Resour. D 2017, 34, 490-498. [CrossRef] 
3. Wei, T.; Wijesiri, B.; Jia, Z.L.; Li, Y.X.; Goonetilleke, X. Re-thinking classical mechanistic model for pollutant build-up on urban impervious surfaces. Sci. Total Environ. 2019, 651, 114-121. [CrossRef] [PubMed]

4. Zhu, Z.H.; Chen, X.H. Evaluating the effects of low impact development practices on urban flooding under different rainfall intensities. Water 2017, 9, 548. [CrossRef]

5. Shariat, R.; Roozbahani, A.; Ebrahimian, A. Risk analysis of urban stormwater infrastructure systems using fuzzy spatial multi-criteria decision making. Sci. Total Environ. 2019, 647, 1468-1477. [CrossRef] [PubMed]

6. Zarezadeh, V.; Lung, T.; Dorman, T.; Shipley, H.J.; Giacomoni, M. Assessing the performance of sand filter basins in treating urban stormwater runoff. Environ. Monit. Assess 2018, 190, 697. [CrossRef]

7. Ivanovsky, A.; Belles, A.; Criquet, J.; Dumoulin, D.; Noble, P.; Alary, C.; Billon, G. Assessment of the treatment efficiency of an urban stormwater pond and its impact on the natural downstream watercourse. J. Environ. Manag. 2018, 226, 120-130. [CrossRef]

8. Mullaney, J.; Lucke, T. Practical review of pervious pavement designs. Clean-Soil Air Water 2014, 42, 111-124. [CrossRef]

9. Liu, R.T.; Liu, H.J.; Sha, F.; Yang, H.L.; Zhang, Q.S.; Shi, S.S.; Zheng, Z. Investigation of the porosity distribution, permeability, and mechanical performance of pervious concretes. Processes 2018, 6, 78. [CrossRef]

10. Zhang, J.; She, R.; Dai, Z.X.; Ming, R.P.; Ma, G.D.; Cui, X.Z.; Li, L. Experimental simulation study on pore clogging mechanism of porous pavement. Constr. Build. Mater. 2018, 187, 803-818. [CrossRef]

11. Castillo-García, G.; Borinaga-Treviño, R.; Sañudo-Fontaneda, L.A.; Pascual-Muñoz, P. Influence of pervious pavement systems on heat dissipation from a horizontal geothermal system. Eur. J. Environ. Civ. Eng. 2013, 17, 956-967. [CrossRef]

12. Ngohpok, C.; Sata, V.; Satiennam, T.; Klungboonkrong, P.; Chindaprasirt, P. Mechanical properties, thermal conductivity, and sound absorption of pervious concrete containing recycled concrete and bottom ash aggregates. KSCE J. Civ. Eng. 2018, 22, 1369-1376. [CrossRef]

13. Xia, J.; Zhang, Y.Y.; Xiong, L.H.; He, S.; Wang, L.F.; Yu, Z.B. Opportunities and challenges of the Sponge City construction related to urban water issues in China. Sci. China Earth Sci. 2017, 60, 652-658. [CrossRef]

14. Du, S.Q.; Shi, P.J.; Rompaey, A.V.; Wen, J.H. Quantifying the impact of impervious surface location on flood peak discharge in urban areas. Nat. Hazards 2015, 76, 1457-1471. [CrossRef]

15. Liu, H.; Jia, Y.W.; Niu, C.W. "Sponge city" concept helps solve China's urban water problems. Environ. Earth. Sci. 2017, 76, 473. [CrossRef]

16. Kim, H.K.; Lee, H.K. Acoustic absorption modeling of porous concrete considering the Gradation and shape of aggregate sand void ratio. J. Sound Vib. 2010, 329, 866-879. [CrossRef]

17. Lund, S.M.M.; Hansen, K.K.; Brincker, R.; Jensen, A.H.; Amador, S.D.R. Evaluation of freeze-thaw durability of pervious concrete by use of operational modal analysis. Cem. Concr. Res. 2018, 106, 57-64. [CrossRef]

18. Zhong, R.; Wille, K. Influence of matrix and pore system characteristics on the durability of pervious concrete. Constr. Build. Mater. 2018, 162, 132-141. [CrossRef]

19. Zhong, R.; Leng, Z.; Poon, C.S. Research and application of pervious concrete as a sustainable pavement material: A state-of-the-art and state-of-the-practice review. Constr. Build. Mater. 2018, 183, 544-553. [CrossRef]

20. Onuaguluchi, O.; Panesar, D.K. Hardened properties of concrete mixtures containing pre-coated crumb rubber and silica fume. J. Clean. Prod. 2014, 82, 125-131. [CrossRef]

21. Bhattacharya, M.; Harish, K.V. An integrated approach for studying the hydration of portland cement systems containing silica fume. Constr. Build. Mater. 2018, 188, 1179-1192. [CrossRef]

22. Xu, W.T.; Lo, T.Y.; Wang, W.L.; Ouyang, D.; Wang, P.G.; Xing, F. Pozzolanic reactivity of silica fume and ground rice husk ash as reactive silica in a cementitious system: A comparative study. Materials 2016, 9, 146. [CrossRef]

23. Zivica, V. Sulfate resistance of the cement materials based on the modified silica fume. Constr. Build. Mater. 2000, 14, 17-23. [CrossRef]

24. Wu, W.J.; Wang, R.; Zhu, C.Q.; Meng, Q.S. The effect of fly ash and silica fume on mechanical properties and durability of coral aggregate concrete. Constr. Build. Mater. 2018, 185, 69-78. [CrossRef]

25. Zhu, Y.; Zhang, Z.C.; Yang, Y.G.; Yao, Y. Measurement and correlation of ductility and compressive strength for engineered cementitious composites (ECC) produced by binary and ternary systems of binder materials: Fly ash, slag, silica fume and cement. Constr. Build. Mater. 2014, 68, 192-198. [CrossRef] 
26. Zhang, Z.Q.; Zhang, B.; Yan, P.Y. Comparative study of effect of raw and densified silica fume in the paste, mortar and concrete. Constr. Build. Mater. 2016, 105, 82-93. [CrossRef]

27. Amornsrivilai, P.; Tia, M.; Lee, M.G.; Su, Y.M. Effects of fly ash and silica fume on permeability of concrete made with porous limestone and non-porous aggregates. J. Test. Eval. 2017, 45, 335-345. [CrossRef]

28. Mondal, S.; Biligiri, K.P. Crumb rubber and silica fume inclusions in pervious concrete pavement systems: Evaluation of hydrological, functional, and structural properties. J. Test. Eval. 2018, 46, 892-905. [CrossRef]

29. Zhang, Y.M.; Qi, H.P.; Li, Y.Q.; Zhang, Y.F.; Sun, J.M. Preparation and characterization of a porous silicate material from silica fume. Korean J. Chem. Eng. 2017, 34, 3185-3194. [CrossRef]

30. Mann, D.A. The Effects of Utilizing Silica Fume in Portland Cement Pervious Concrete. Master's Thesis, University of Missouri-Kansas City, Kansas City, MO, USA, 2014.

31. Zerdi, T.A.; Samee, M.A.; Ali, H.; Zerdi, T. Study of silica fume incorporation in pervious concrete. Int. J. Sci. Res. 2016, 5, 532-533.

32. Liu, H.B.; Luo, G.B.; Wei, H.B.; Yu, H. Strength, permeability, and freeze-thaw durability of pervious concrete with different aggregate sizes, porosities, and water-binder ratios. Appl. Sci. 2018, 8, 1217. [CrossRef]

33. Liu, H.B.; Luo, G.B.; Gong, Y.F.; Wei, H.B. Mechanical properties, permeability, and freeze-thaw resistance of pervious concrete modified by waste crumb rubbers. Appl. Sci. 2018, 8, 1843. [CrossRef]

34. Ministry of Housing and Urban-Rural Construction of the People's Republic of China. Technical Specification for Pervious Cement Concrete Pavement; Ministry of Housing and Urban-Ural Construction of the People's Republic of China: Beijing, China, 2009. (In Chinese)

35. Ministry of Housing and Urban-Rural Construction of the People's Republic of China. Standard for Test Method of Mechanical Properties on Ordinary Concrete; Ministry of Housing and Urban-Ural Construction of the People's Republic of China: Beijing, China, 2002. (In Chinese)

36. Ministry of Housing and Urban-Rural Construction of the People's Republic of China. Standard for Test Methods of Long-Term Performance and Durability of Ordinary Concrete; Ministry of Housing and Urban-Ural Construction of the People's Republic of China: Beijing, China, 2009. (In Chinese)

(C) 2018 by the authors. Licensee MDPI, Basel, Switzerland. This article is an open access article distributed under the terms and conditions of the Creative Commons Attribution (CC BY) license (http:/ / creativecommons.org/licenses/by/4.0/). 